\title{
Working capital management in the process of financial support of investment and construction projects and of the construction material industry
}

\author{
Nadezhda Danilochkina ${ }^{1, *}$ Inessa Lukmanova ${ }^{2}$, Olga Roshchina $^{3}$, Nikolay Voytolovskiy ${ }^{4}$ \\ ${ }^{1}$ Moscow Aviation Institute (National Research University), Volokolamskoe highway, 4, Moscow, \\ 125993, Russia \\ ${ }^{2}$ Moscow State University of Civil Engineering, Yaroslavskoye sh., 26, 129337 Moscow, Russia \\ ${ }^{3}$ Metropolitan Financial and Humanitarian Academy, Shosseinaya str., 90/17, Moscow, 117623, \\ Russia \\ ${ }^{4}$ Sankt-Petersburg State Economic University, Sadovaya street, 21, St. Petersburg, 191023, Russia
}

\begin{abstract}
The article presents the analysis of working capital in the process of financial support of high-rise construction investment projects. The factors influencing the choice of the working capital management model were analyzed, the reasons of the change in the requirement for the values of current assets in the process of construction of high-rise facilities were determined. The author has developed the scheme of interrelation between production, operational and financial activity cycles of enterprises implementing investment projects of unique buildings and structures and made a comparative description of their financing sources.
\end{abstract}

\section{Introduction}

In order to provide an uninterrupted production process of the company, it is necessary to purchase primary products, materials, containers, etc. For the permanence of the output realization, the business entity should accumulate certain volumes of end construction products. Calculations for finished products extract cash from the turnover, sometimes creating accounts receivable. In order to maintain liquidity, the company can temporarily place free cash into various short-term investments, which should have high liquidity and be able to be freely converted back into monetary assets. The own working capital of the company, its composition and structure, the turnover speed and efficiency of working capital use predetermine the status of the company and the stability of its position in the financial market [1]. J. Brigham and L. Gapenski, the leading experts in the field of financial management, note that short-term financial decisions imply management of cash flows expected in the nearest future (within the current year). The origin of most of these cash flows is associated with transactions relating to working capital and short-term liabilities.

\section{Methods}

* Corresponding author: nadanilochkina@yandex.ru 
Financing of the current activity of the company is related to the financing of current assets and the development of a perfect mechanism for managing the company's current assets. The effective application of such a mechanism in practice is an extremely urgent problem today, as the effective formation and regulation of the volume of current assets helps maintaining a preferable level of liquidity, ensures the promptness of the production and financial activity cycles, and as the result sufficiently high paying capacity and financial stability of companies.

This explains the importance of the working capital's role in the financial provision of the activity of the company.

The definition of current assets formulated by I.A. Blank also reveals the essence and importance of working capital in ensuring the current activity of the organization. Under current assets, he implies assets characterizing the complex of property values of the company that serve the current production and commercial (operational) activities and are fully consumed within one production and commercial cycle.

E. M. Shakhbazyan distinguishes several differences between working capital and current assets (Figure 1).

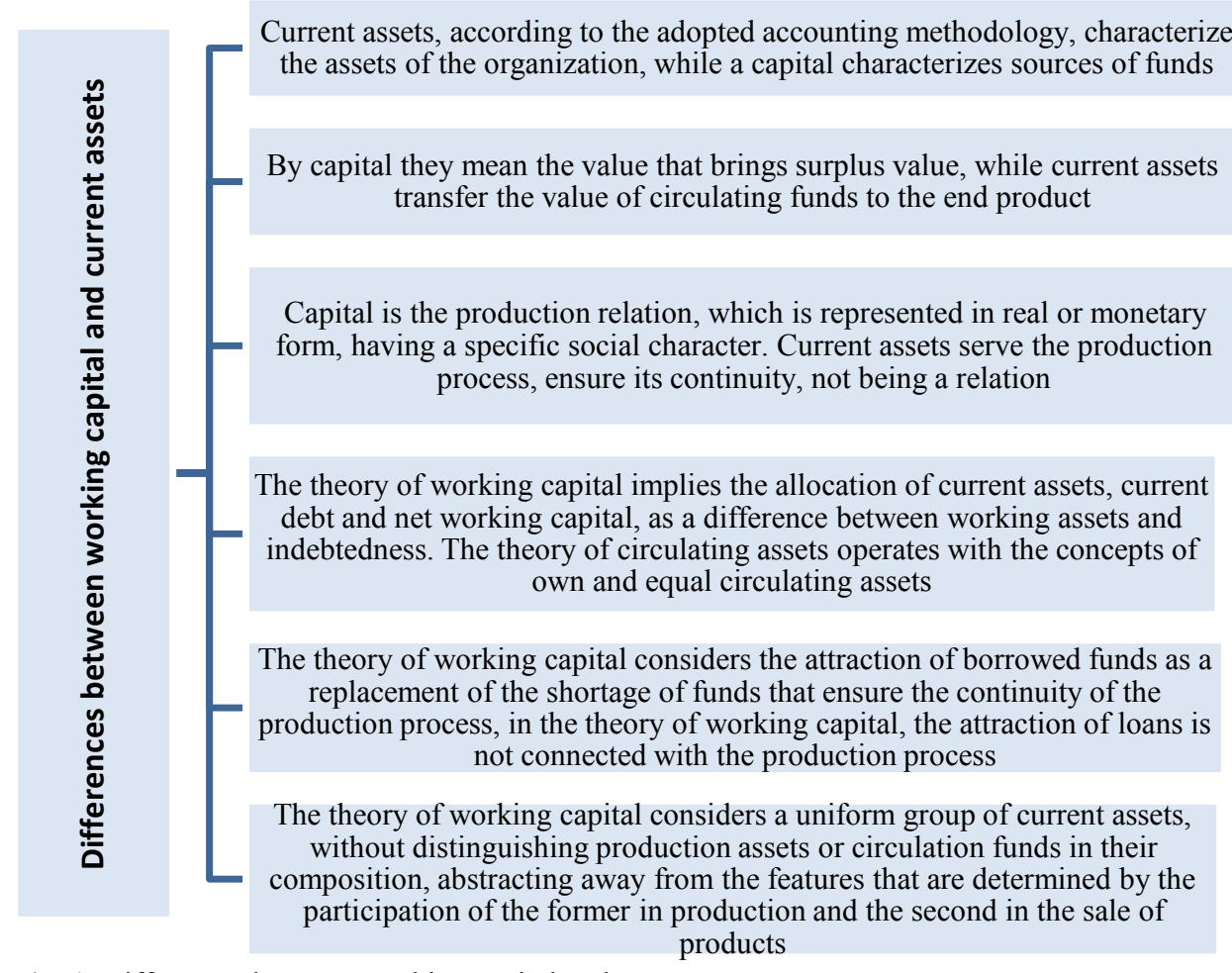

Fig. 1. Differences between working capital and current assets

The current assets' management policy and current assets themselves are important primarily in terms of ensuring the continuity and effectiveness of the current activities of the company. As V.V. Kovalev assumes, the change in current assets is accompanied by a change in short-term obligations, therefore both objects of accounting should be considered together in terms of the policy of net working capital management.

Current asset management includes the work of the administration on the development of the main direction of the policy concerning current assets, and specifically the ways to finance them [2].

By the policy of management of current assets, I. A. Blank means part of the overall financial strategy of the company, consisting in the formation of the necessary volume and 
composition of current assets, rationalization and optimization of the structure of their sources of financing.

\section{Results}

In order to justify the choice of the volume of short-term loans for financing investment construction projects, S. Ross, R. Westerfield and B. Jordan suggest analyzing the following factors:

- monetary reserves. A flexible financial policy implies a surplus of money and small short-term loans. This policy reduces the chance that the company will experience a financial famine.

- insurance of urgency. Most organizations aim to reconcile the urgency of assets and liabilities. They finance stocks through short-term bank loans, and fixed assets through long-term financing. Organizations try to avoid financing long-term assets through shortterm loans. Such a mixture of urgency of payments makes frequent refinancing necessary and is risky, as short-term interest rates are more volatile than long-term rates.

- relative interest rates. Short-term interest rates are usually lower than long-term ones. This means that in most cases it is less profitable to resort to long-term loans than to short-term loans.

Management of current assets of the company is associated with specific features of the formation of its operational cycle, which characterizes the time interval between the acquisition of production reserves and the receipt of cash from sales of the products produced of these reserves. The constant process of circulation of the assets under consideration is graphically presented in Figure 2 [3].

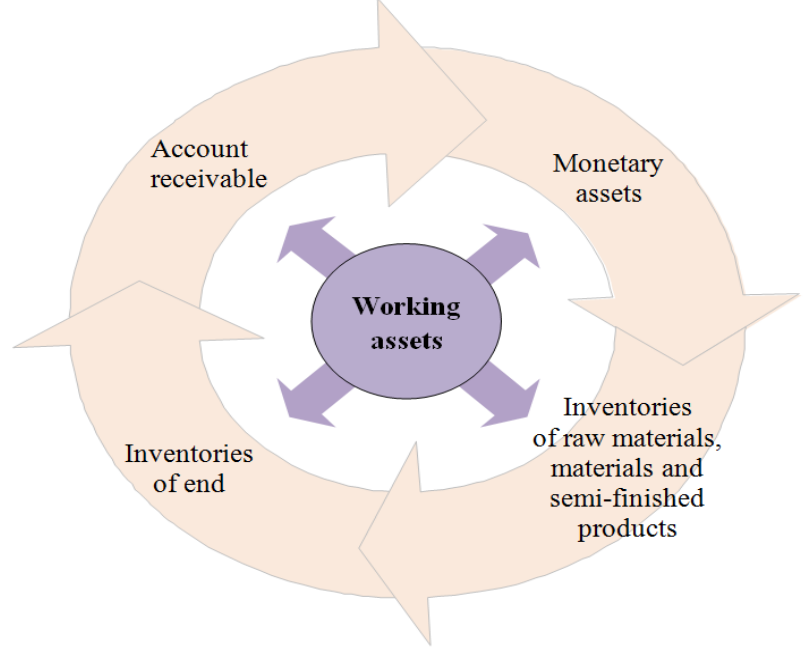

Fig. 2. Characteristics of the movement of current assets within the process of their circulation

The flow of the current assets of the organization goes through four main stages within the process of their circulation, consistently changing their forms [4]:

1. Stage 1 - monetary assets are used to purchase raw materials;

2. Stage 2 - reserves of tangible current assets are converted into finished products due to production activities;

3. Stage 3 - finished products are sold to consumers and converted into current receivables before the payment

4. Stage 4 - current receivables are re-converted into cash assets. 
Developing the position formulated by J. Brigham and L. Gapenski, V.V. Kovalev draws attention to the fact that the definition of the volume and structure of working capital, the sources of their coverage and the relationship between them is the objective of working capital management. He assumes that this will be sufficient to ensure the long-term productive and efficient financial activities of the company.

The stated objective is strategic. The subject matter of the same importance is the maintenance of working capital of the amount optimizing the management of current activities. In these terms, its liquidity is the most important financial and economic attribute of the company [5].

In this regard, the importance of liquidity management along with the management of circulating assets arises. According to J. Brigham and L. Gapensky, liquidity management includes planning for the entry and use of liquid resources in such a way as to be able to pay off their short-term obligations on time (Figure 3).

From all of the above, it follows that liquidity management is a broader concept than working capital management, since it involves planning sales of permanent assets, issuing long-term securities and evaluating any other long-term projects that affect the organization's liquidity.

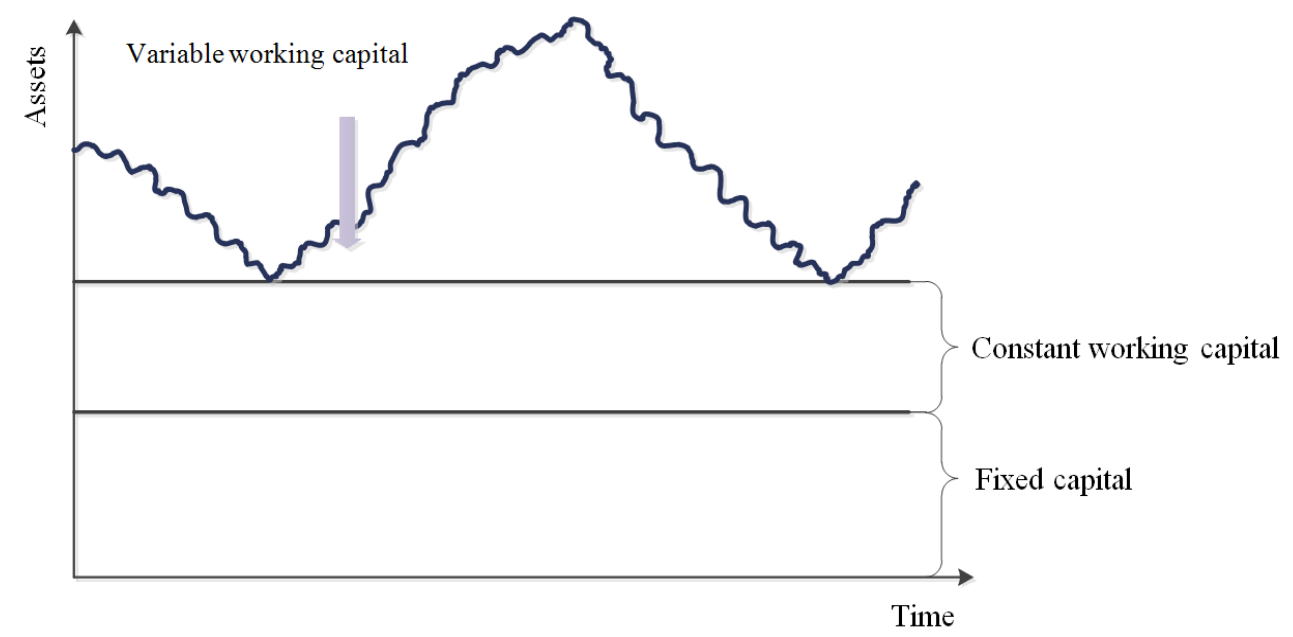

Fig. 3. Constant and variable working capital as components of a dynamic range of assets of the organization

Working capital is usually divided according to the period of the functioning of current assets into a constant (or system) capital and variable capital [6].

The first category of obligations relates to the management of both current assets and liquidity, while the second relates only to managing liquidity.

V.V. Kovalev assumes that the task-oriented management of current assets of the organization determines the need for their prior classification. In terms of financial management, this classification of current assets is based on the following main features, which are graphically presented in Figure 4. 


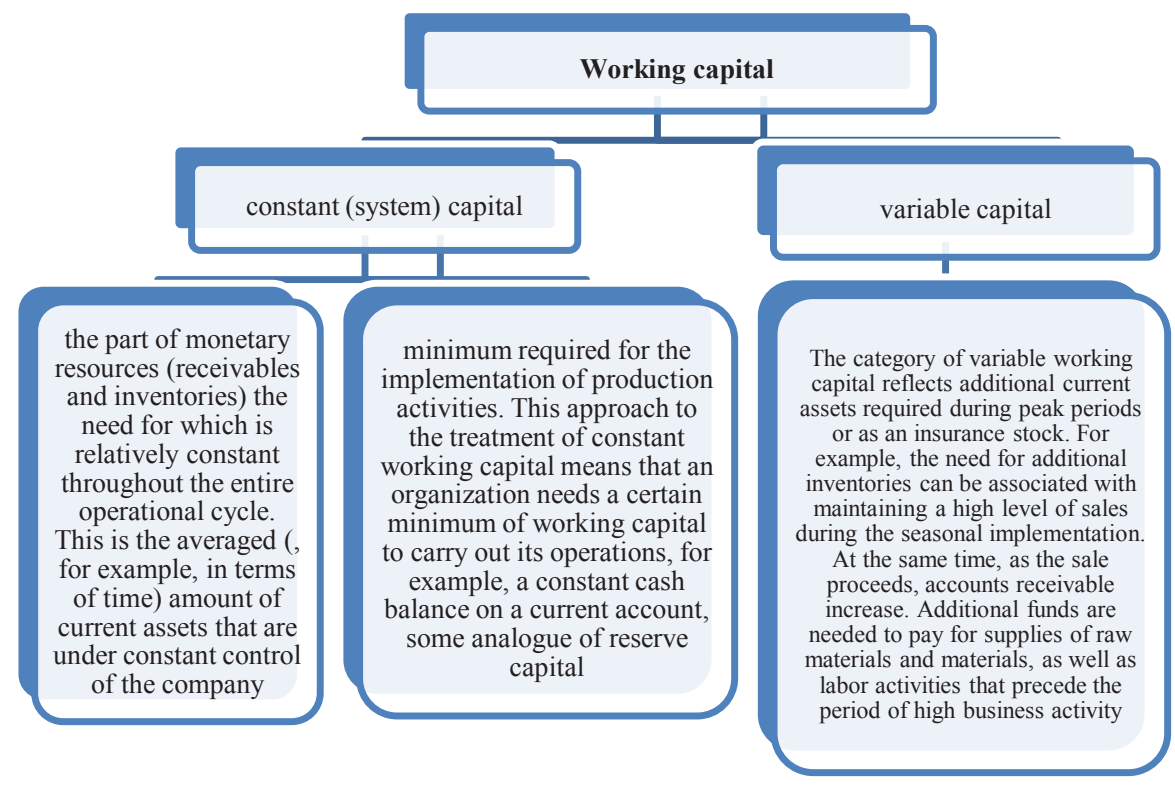

Fig. 4. Working capital breakdown

The level of working capital is directly related to the risk of liquidity loss and the amount of profit. Due to this, the working capital management policy should provide finding a compromise between the risk of liquidity loss and efficiency of work. It comes down to solving two important problems [7]:

1) Ensuring solvency. There is no solvency, when a company is not able to fulfill obligations and can possibly declare bankruptcy. A company that does not have sufficient working capital can face insolvency risk.

2) Ensuring an acceptable volume, structure and profitability of assets. Because different current assets have different effects on profits, a high level of reserves will require significant expenses. In turn, end products can help increase sales volumes and increase revenues in the future. Decisions related to the determination of the level of different groups of current assets should be considered both in terms of the profitability of this type of assets and in terms of $\mathrm{m}$ the position of their optimal structure.

In work [2] a clear sequence of stages of implementation of the management policy for current assets is formed, which is graphically presented in Figure 5.

Taking into account the considered features of management of current assets, it should be mentioned that each of the components of current assets has its own features [8]:

- 1. the justification of the reserves should be based on the calculation of the optimal delivery schedule and the average daily balance, taking into account an effective control system for their movement

- 2. management of accounts receivable implies not only an analysis of the dynamics of its state, its specific gravity, composition and structure for the previous period, but also the formation of a credit policy with respect to purchasers of products, a credit system, and systematic monitoring of debtors

- 3. cash management involves not only monitoring the level of absolute liquidity, but also optimizing the average balance of all cash on the basis of calculations of operational, insurance, compensation and investment reserves 




Fig. 5. The main stages of the formation of policy of managing current assets of the company

\section{Discussions}

Short-term financial decisions are made within the short-term financial planning, the main task of which is to provide and maintain the liquidity of the company. A liquid company is able to carry out its current activities. That means that it has sufficient funds to make the necessary payments to employees, suppliers and investors, pay taxes, etc. Conversely, a company that is not liquid cannot find the funds needed for these payments in a short time, which leads to a disruption of current operations. Current assets are used to create funds that are not aimed at a certain period. The description of this process is more complete, because they directly provide the procedure of processing and conversion, selling products, as well as the formation of monetary resources and their expenditure.

\section{Conclusion}

Thus, financial stability management is an important aspect of the financial and economic departments of a company and includes a number of organizational activities covering 
planning, operational management and the creation of a flexible coordination structure for the management of the entire company and its departments. Particular attention is paid to the effective use of working capital, which takes a great part in ensuring the normalization of the company's work.

\section{References}

1. R. S. Golov, V. V. Shilov, S. A. Silantiev ASEE International Forum, Columbus , Ohio. June 28, Paper ID \#20766. (2017)

2. E. Nezhnikova Procedia Engineering 165 1300-1304 (2016) doi: 10.1016/j.proeng.2016.11.854

3. A. Jones, G. Fallon, R. Golov European Business Review, 12-4, pp.187-197, doi. 10.1108/09555340010336871

4. I.V. Ilin, A.I. Levina, O.Yu. Iliashenko, MATEC Web of Conf, 86, 05028 (2016) DOi $10.1051 /$ matecconf $/ 20168605028$

5. I.V. Ilin, O. Kalinina, O. Iliashenko, A. Levina, Procedia Engineering, 165, pp 16731682 (2016) DOi - 10.1016/j.proeng.2016.11.909

6. I. Zaychenko, S. Gutman, O. Kalinina, Advances in Intelligent Systems and Computing, 692, pp 453-462 (2018) DOi - 10.1007/978-3-319-70987-1_48

7. A. Borboni F. Aggogeri A. Merlo, N. Pellegrini, CAmici 2015 International Journal of Advanced Robotic Systems, 12, art. no. 42. DOI: 10.5772/60052

8. V. Pukhkal, V. Murgul, M. Garifullin Procedia Engineering 117 624-627 (2015) 